\title{
Early infant HIV-1 diagnosis programs in resource- limited settings: opportunities for improved outcomes and more cost-effective interventions
}

\author{
Andrea L Ciaranello ${ }^{1 *}$, Ji-Eun Park², Lynn Ramirez-Avila ${ }^{1,3}$, Kenneth A Freedberg ${ }^{1,2,4}$, Rochelle P Walensky ${ }^{1,2,4,5}$ and \\ Valeriane Leroy ${ }^{6}$
}

\begin{abstract}
Early infant diagnosis (EID) of HIV-1 infection confers substantial benefits to HIV-infected and HIVuninfected infants, to their families, and to programs providing prevention of mother-to-child transmission (PMTCT) services, but has been challenging to implement in resource-limited settings. In order to correctly inform parents/caregivers of infant infection status and link HIV-infected infants to care and treatment, a 'cascade' of events must successfully occur. A frequently cited barrier to expansion of EID programs is the cost of the required laboratory assays. However, substantial implementation barriers, as well as personnel and infrastructure requirements, exist at each step in the cascade. In this update, we review challenges to uptake at each step in the EID cascade, highlighting that even with the highest reported levels of uptake, nearly half of HIV-infected infants may not complete the cascade successfully. We next synthesize the available literature about the costs and cost effectiveness of EID programs; identify areas for future research; and place these findings within the context of the benefits and challenges to EID implementation in resource-limited settings.
\end{abstract}

\section{Introduction}

Mother-to-child transmission (MTCT) of HIV-1 results in approximately 370,000 infant infections worldwide each year [1]. HIV-1 early infant diagnosis (EID) programs seek to inform the caregivers of HIV-exposed infants of infant HIV infection status, and to link HIV-

\footnotetext{
* Correspondence: aciaranello@partners.org

'Division of Infectious Disease, Massachusetts General Hospital, Boston, MA, USA

Full list of author information is available at the end of the article
}

infected infants to care and treatment. EID of HIV confers substantial benefits to infants and families, both for HIV-infected and uninfected infants, as well as to programs providing prevention of mother-to-child transmission (PMTCT) services. The World Health Organization (WHO) estimates that only $6 \%$ to $15 \%$ of HIV-exposed infants under 1 year of age accessed EID programs in 2008-2009 [2], highlighting that the implementation of effective EID programs has been challenging in resource-limited settings and demands careful attention.

A frequently cited barrier to expansion of EID programs is the availability and cost of the required laboratory assays, which are usually PCR based and therefore more expensive than the antibody-based testing used for older children and adults [3,4]. However, cost is not the only barrier to implementing EID programs. Opportunities to optimize infant outcomes may be lost at each step in a 'cascade' of EID and pediatric HIV care (Figure $1)$, conceptually similar to the recently described 'cascade' of care required for effective PMTCT services [5]. The EID cascade includes the offer and acceptance of EID testing among HIV-exposed infants, including those for whom HIV exposure was unknown; accurate specimen collection, transport, and laboratory processing; relay of results to both healthcare providers and infants' families/caregivers; and linkage to care, cotrimoxazole prophylaxis, and antiretroviral therapy (ART) for infants identified as HIV infected. In this review, we outline the ways in which interventions targeting each step in this EID cascade may impact clinical outcomes, costs, and cost effectiveness of EID programs.

\section{Currently available assays for early infant diagnosis}

In adults and older children, chronic HIV-1 infection can be diagnosed accurately by detection of serum 


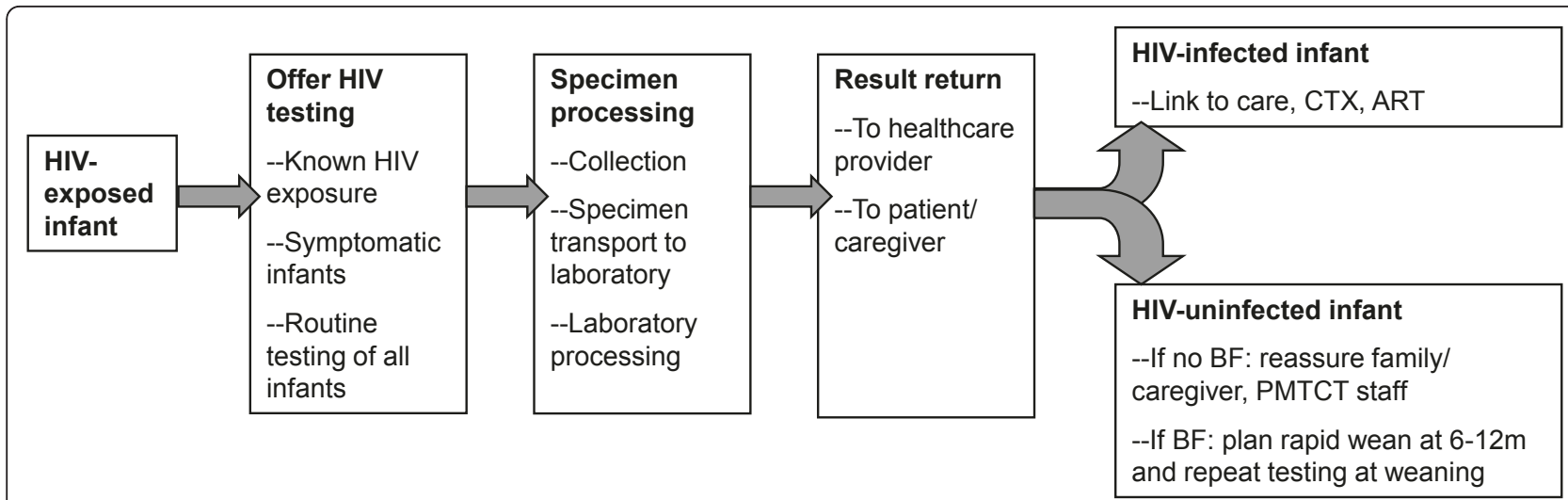

Figure 1 Early infant diagnosis (EID) cascade: where could interventions be most effective and cost effective? The cascade of care required for optimally effective EID programs, with two primary goals: (1) correctly informing caregivers of infant infection status and (2) linking all HIV-infected infants to care and antiretroviral therapy (ART). BF = breastfeeding; CTX = cotrimoxazole; PMTCT = prevention of mother-to-child HIV transmission.

antibodies against HIV-1 [6]. However, in infants born to HIV-infected women, maternal anti-HIV antibodies cross the placenta and persist in infant blood for up to 18 months (Figure 2). When detected in young infants, these antibodies usually represent exposure to maternal HIV rather than true infant HIV infection $[7,8]$. Antibody-based tests can therefore be accurately used only to exclude infant infection after 12 months of age, or to confirm infant infection after 15-18 months of age [6,9].

Accurate EID before 12-18 months of age therefore requires detection of viral components in infant blood ('virological testing'), including cell-free RNA, DNA integrated into host cells, or the viral capsid p24 antigen. Both RNA and DNA can be detected by PCR-based assays. DNA PCR assays, which provide a qualitative result, have traditionally been preferred for EID over quantitative RNA PCR assays, which are more often used for viral load monitoring after established diagnosis. This preference for DNA PCR assays developed for two primary reasons: (1) DNA assays require whole blood, which is easier to obtain than the plasma required for RNA assays, and (2) early-generation DNA assays demonstrated greater sensitivity than RNA assays if mothers or infants received antiretroviral drugs for PMTCT [10-14]. Multiple RNA and DNA PCR assays are now used for EID in resource-limited settings; the sensitivity, specificity, and limitations of these assays have been well summarized [11,12,15-19]. In addition to PCR assays, ultrasensitive (immune complex-dissociated) p24 antigen assays may soon represent an accurate, lowcost method for EID [8,11,15,20-27]. Furthermore, the use of dried blood spots (DBS; whole blood obtained via heel stick or finger prick and dried on filter paper) has obviated phlebotomy requirements for all three assay types. Because DBS specimens are heat stable, non- infectious, and can be shipped via mail or courier, DBS sampling has also reduced the cost of specimen transport to laboratories with PCR or p24 processing capacity $[8,20,21,28-32]$.

\section{Assays for early HIV diagnosis among breastfed infants}

Breastfed infants are at ongoing risk of postnatal HIV acquisition [6]. A positive virological test result in a breastfed infant indicates infant HIV infection; however, virological tests may be falsely negative immediately after postnatal infection has occurred (Figure 2). HIV care and treatment guidelines therefore recommend that HIV infection in an HIV-exposed infant cannot be definitively excluded until at least 6 weeks after cessation of breastfeeding [10]. Additionally, breastfeeding in many settings may continue through the first 2-3 years of life, suggesting an important role for repeat testing, both during the breastfeeding period, to detect incident infant infections, and at least 6 weeks after weaning, to confirm HIV-negative diagnoses.

\section{Benefits of early infant diagnosis}

The Children with HIV Early ART (CHER) trial in South Africa recently demonstrated a $76 \%$ reduction in morbidity, a $75 \%$ reduction in mortality, and notable short-term cost reductions when HIV-infected infants initiated ART before 3 months of age and before clinical signs and symptoms of HIV developed $[33,34]$. Based on this trial and a growing body of observational data [35-37], WHO pediatric treatment guidelines now recommend ART initiation for all HIV-infected infants under 24 months of age [6,32]. In order to facilitate ART initiation as soon as possible after infection, WHO recommends HIV diagnostic testing for all HIV-exposed 


\section{2a. HIV -exposed, Uninfected Infant}

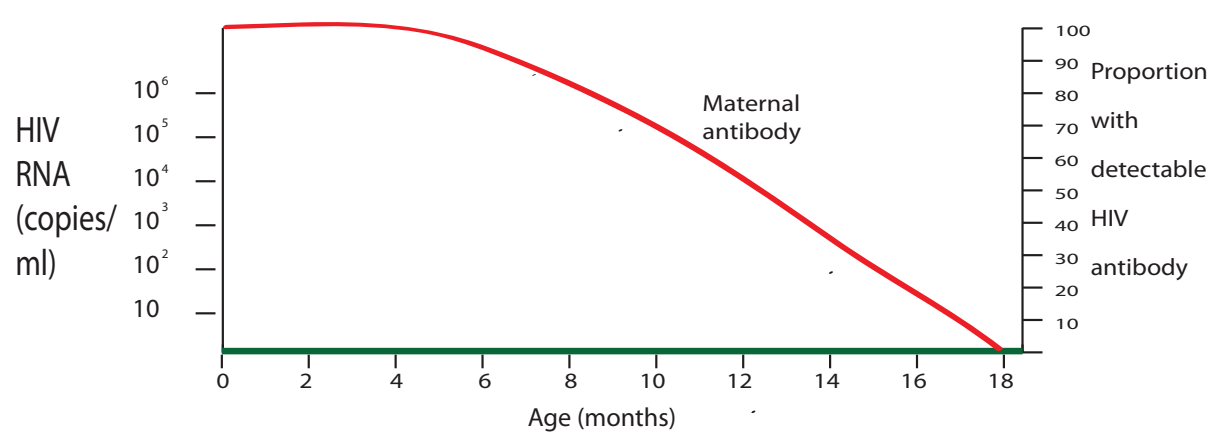

2b. HIV-infected Infant: Intrauterine or Intrapartum Infection

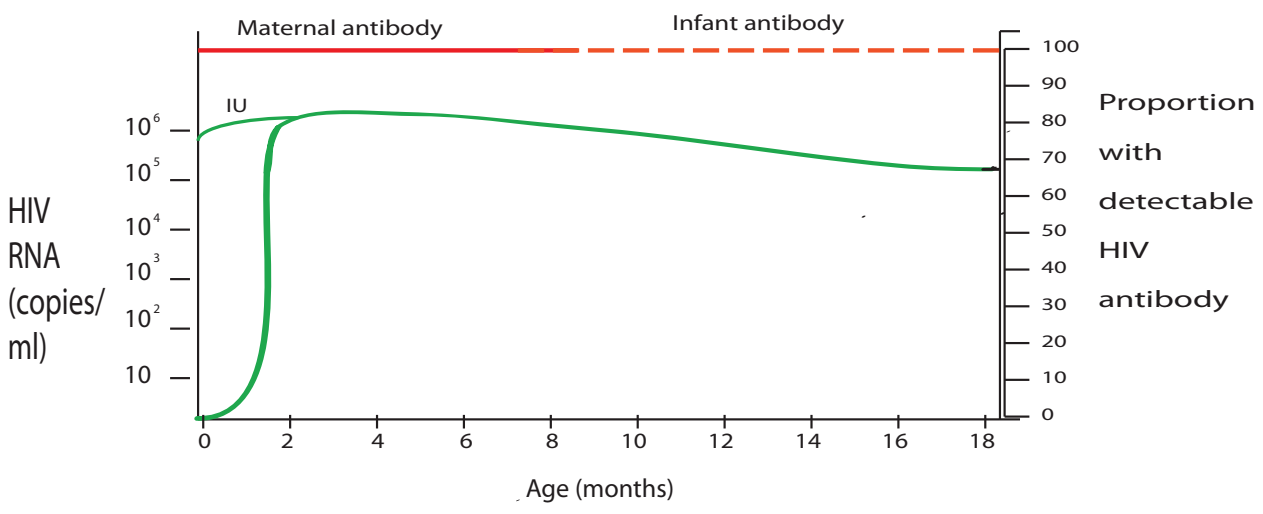

2c. Postnatal (Breastfeeding) Infection

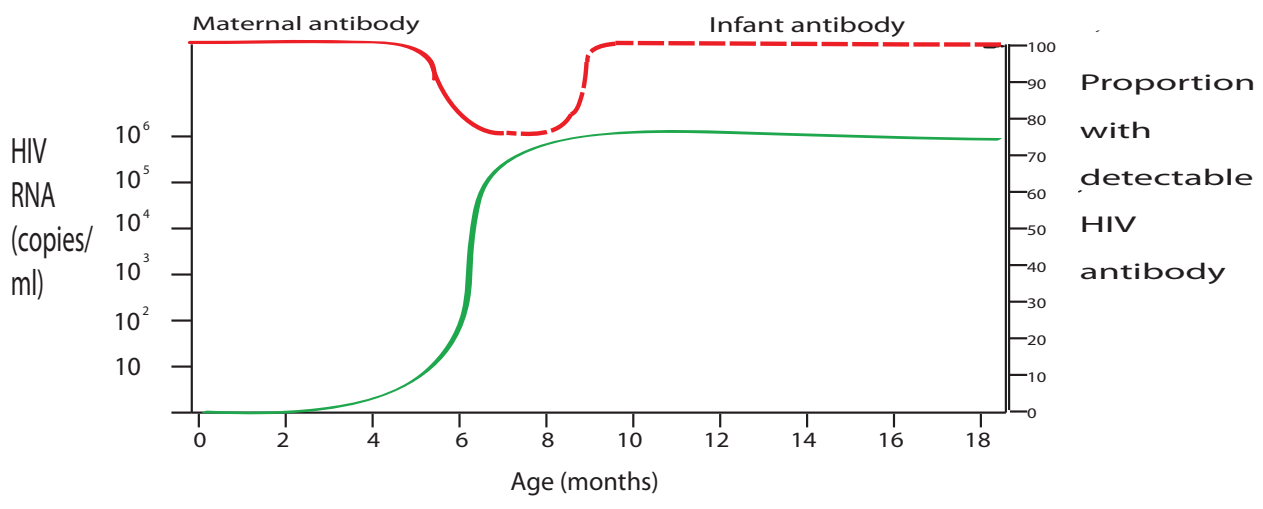

Figure 2 HIV RNA levels and anti-HIV antibody responses among HIV-exposed infants with and without HIV infection. Schematic depiction of the timing of positive HIV-1 antibody testing and RNA levels among HIV-exposed infants. The horizontal axis shows infant age in months. The left vertical axis shows mean HIV-1 RNA level on a logarithmic scale, and corresponds to the green lines on each graph. The right vertical axis shows the proportion of infants for whom an HIV antibody test would likely return positive, and corresponds to the red lines on each graph. The proportion of infants with a positive antibody test in all panels is approximate, based on a wide range of reported ages at which transmitted maternal HIV antibody fades from detection in the sera of uninfected infants [7,105]. Similarly, the mean RNA level is also approximate, based on several studies of infected infants with and without receipt of antiretroviral drugs for prevention of mother-to-child HIV transmission (PMTCT) [106-109]. (a) Results for an HIV-exposed infant who is born without HIV infection and remains uninfected throughout breastfeeding. In this case, HIV-RNA level remains zero, and maternal HIV antibody fades with time. (b) Results for infants infected before birth, either during the intrauterine period (IU; resulting in a high RNA level immediately after birth) or during the intrapartum period (IP; resulting in a 1-2 week delay before viremia is detectable). Maternal HIV antibody is present at birth; although maternal antibody fades with time, endogenous infant antibody production begins in response to infant infection. (c) Results for an HIV-exposed infant who is uninfected at birth, but becomes infected at approximately 6 months of age through breastfeeding. HIV RNA is undetectable while the infant is uninfected, but rises rapidly within the first few weeks after infection. Maternal antibody is present at birth and begins to fade with time, but infant antibody production begins after infant infection occurs. 
infants (infants born to HIV-infected mothers) at 4-6 weeks of age [32].

EID confers many potential benefits in addition to early ART initiation. As PMTCT programs are expanded, the majority of HIV-exposed infants will be uninfected and negative virological tests in infancy will provide reassurance to families [11]. In addition, when HIV-exposed infants are raised by extended families due to maternal disability or death, caregivers may bond more readily to infants known to be HIV negative [38]. Documented infant HIV status also permits assessment of PMTCT program effectiveness, and the recognition that a large proportion of HIV-exposed infants are uninfected has improved morale among PMTCT program staff [11].

Accurate EID also informs infant feeding decisions in settings where breastfeeding is recommended for improved infant health. For example, if infants are found to be HIV infected, WHO recommends breastfeeding for 2 years or longer, to avoid the increased incidence of diarrhea, pneumonia, and death observed with replacement feeding $[39,40]$. A diagnosis of HIV infection also permits discontinuation of postnatal antiretroviral prophylaxis, reducing the risk of drug-resistant virus associated with these medications [41,42]. If infants are found to be uninfected, decisions to avoid early mixed feeding and to shorten the duration of breastfeeding to 12 months can preserve many of the benefits of breastfeeding, while reducing the risk of HIV infection [11,43-45].

\section{The EID 'cascade' in resource-limited settings}

Access to virological tests for EID has been limited in many resource-constrained settings, and pediatric providers have often relied on infant diagnosis algorithms that combine clinical symptoms with infant antibody testing [10,46-48]. As described above, these algorithms are neither sensitive nor specific in young infants [49], and HIV diagnosis and ART initiation often occur well after infancy [50,51]. Since 2005, PMTCT and pediatrics programs report rapidly expanding access to EID and infant ART [52]. Published and presented reports emphasize that DBS RNA [53,54] and DNA [1,3,28,31,55-71] PCR assays are feasible and acceptable for EID in resource-limited settings. However, these reports highlight that many infants are lost from care at each step in the EID cascade (Figure 1), including: infant presentation to care, test offer by healthcare professionals and test acceptance by parents/caregivers, specimen processing, result return to healthcare facilities and parents/caregivers, and linkage to care. Reported experiences of EID programs in resource-limited settings are summarized in Table 1. Many of these reports suggest high losses to follow-up at each step in the EID cascade, which likely have important impacts on the clinical outcomes, costs, and cost effectiveness of EID programs.

\section{Proportion of HIV-exposed infants undergoing EID testing}

A large proportion of HIV-exposed infants never enter the EID pathway. To undergo EID testing, an infant must be brought by a caregiver to a healthcare facility, and healthcare providers must offer EID testing to the infant/caregiver pair. Most EID programs target infants for whom maternal HIV infection is already known (Table 1). Focusing testing efforts only on these known HIV-exposed infants may result in missed testing opportunities for more than half of all truly HIV-exposed infants [4,71-73].

Even when HIV-infected mothers are aware of their own HIV infection, this information may not be shared with pediatric providers, for example if the importance of disclosure is not emphasized, if mothers are reluctant to disclose their HIV infections, or if infants are brought to care by non-maternal caregivers $[68,71,73]$. Strategies to improve linkage between PMTCT and pediatric records are under investigation, and include child health cards indicating maternal HIV status [74] and integrated maternal and child health programs $[75,76]$.

Such efforts may miss the large number of infants whose mothers are unaware of their own HIV infections. This may occur for many HIV-infected women, as a result of lack of HIV testing in pregnancy or falsenegative HIV antibody tests during acute maternal infection [1]. Importantly, children of women with undiagnosed HIV infection are at substantial risk for HIV infection due to missed opportunities for PMTCT interventions [73,77], and those unknowingly infected in the peripartum or postpartum periods likely have the highest risk of MTCT [77,78]. When HIV diagnosis is unknown, healthcare providers may not consider EID testing necessary, or may feel uncomfortable offering an infant test that will reveal maternal HIV status [68].

To improve testing rates among both known and unknown HIV-exposed infants, several EID programs have broadened their target population to include sick infants presenting to care in inpatient or outpatient settings [3,55,79-81]. However, such programs offer testing when infants develop symptoms suggestive of HIV/ AIDS, obviating the benefits of ART initiation before symptoms develop [33]. An innovative strategy of 'universal testing' of healthy infants at vaccination clinics (regardless of information about maternal HIV status) was found to be feasible and acceptable in South Africa, a high-HIV prevalence setting $[68,82]$. Importantly, parental acceptance of routine infant HIV testing at well child and vaccination visits may be substantially lower in lower-prevalence settings [81]. 
Table 1 Recent reports of early infant diagnostic testing programs in resource-limited settings: loss to follow-up at key steps in the 'cascade' of care

\begin{tabular}{|c|c|c|c|}
\hline $\begin{array}{l}\text { First author, } \\
\text { year, } \\
\text { reference }\end{array}$ & Location & Program, population & Findings \\
\hline \multicolumn{4}{|c|}{ Proportion of HIV-exposed infants undergoing EID testing: } \\
\hline $\begin{array}{l}\text { Creek, } 2008 \\
{[3]}\end{array}$ & Botswana & $\begin{array}{l}\text { Pilot EID program: HIV-exposed infants attending well } \\
\text { child visits, and inpatient and outpatient care settings }\end{array}$ & $\begin{array}{c}\text { Of estimated 1,500 HIV-exposed children attending well child } \\
\text { (clinic) visits, 1,297 (86\%) were tested (total HIV-exposed no. not } \\
\text { estimated for inpatient/outpatient settings) }\end{array}$ \\
\hline $\begin{array}{l}\text { Dow, IAS } \\
2009 \text { [71] }\end{array}$ & Malawi & $\begin{array}{l}\text { Infants of known HIV-infected mothers offered EID at } 6 \\
\text { weeks of age }\end{array}$ & $\begin{array}{l}\text { Of } 646 \text { HIV-infected mothers, } 338 \text { (53\%) presented for EID } \\
\text { testing }\end{array}$ \\
\hline $\begin{array}{l}\text { Kimario, } \\
\text { HAIM } 2009 \\
{[62]} \\
\end{array}$ & Tanzania & $\begin{array}{c}\text { Ministry of Health-supported EID scale-up program: } \\
\text { HIV-exposed infants age } 1-9 \text { months }\end{array}$ & Of 2,128 HIV-exposed infants identified, 2,089 (98\%) were tested \\
\hline $\begin{array}{l}\text { Leroy, IAS } \\
2009 \text { [81] }\end{array}$ & $\begin{array}{l}\text { Côte } \\
\text { d'lvoire }\end{array}$ & $\begin{array}{l}\text { EID program: all infants attending immunization or } \\
\text { outpatient clinics }\end{array}$ & $\begin{array}{l}\text { Of 7,579 eligible, } 3,013 \text { ( } 40 \% \text { ) offered EID testing, and } 447 \\
\text { accepted ( } 15 \% \text { of offered, } 6 \% \text { of total) }\end{array}$ \\
\hline $\begin{array}{l}\text { Rollins, } 2009 \\
{[68]}\end{array}$ & $\begin{array}{l}\text { South } \\
\text { Africa }\end{array}$ & $\begin{array}{l}\text { All mothers/infants attending immunization clinics at } 6 \text {, } \\
\text { 10, or } 14 \text { weeks of age (median } 7.7 \text { weeks) }\end{array}$ & $\begin{array}{l}\text { Of } 646 \text { mothers, } 584 \text { (90\%) agreed to and underwent EID } \\
\text { testing }\end{array}$ \\
\hline $\begin{array}{l}\text { Nuwagaba, } \\
2010[70]\end{array}$ & Tanzania & $\begin{array}{l}\text { Pilot EID program: HIV-exposed infants identified via } \\
\text { maternal status or positive HIV antibody result }\end{array}$ & Of 510 HIV-exposed infants identified, 441 (87\%) were tested \\
\hline $\begin{array}{l}\text { Braun, } 2011 \\
{[110]}\end{array}$ & Malawi & $\begin{array}{l}\text { Retrospective review of ANC, EID, and pediatric ART } \\
\text { programs in Lilongwe, Malawi, 2004-2008 }\end{array}$ & $\begin{array}{l}\text { Of 14,669 HIV-exposed infants identified, 7,875 (54\%) were } \\
\text { tested }\end{array}$ \\
\hline $\begin{array}{l}\text { Hassan, } 2011 \\
{[76]}\end{array}$ & Kenya & $\begin{array}{l}\text { Retrospective review of HIV-exposed infants enrolled in } \\
\text { an HIV clinic in Kilifi District, Kenya, 2006-2008 }\end{array}$ & $\begin{array}{l}\text { Of } 233 \text { HIV-exposed infants enrolled in care, } 156 \text { (67\%) were } \\
\text { tested }\end{array}$ \\
\hline
\end{tabular}

\section{Specimen collection and processing:}

Creek, $2008 \quad$ Botswana As above Of 1,931 samples, 27 (1.4\%) unevaluable due to labeling errors [3]

Khamadi, Kenya Pilot EID program: HIV-exposed infants seen at 6 week Of 9,922 samples, 3 (0.03\%) unevaluable due to errors in

2008 [61] immunization visit specimen collection or packaging

Kouakou, IAS Côte Pilot EID program in 25 PMTCT sites in 10 districts: HIV- Of 588 specimens, 92 (16\%) unevaluable, and an additional 54 2008 [63] d'lvoire $\quad$ exposed infants $\quad$ (9\%) were not evaluated for unspecified reasons

Lofgren, 2009 Tanzania DBS RNA PCR service for remote healthcare facilities Of 223 samples, 27 (12\%) 'lost with assay errors' and 7 (3\%)

[28] specimens hemolyzed or of insufficient quantity

Menzies, Uganda Pilot EID program: HIV-exposed infants age 6 weeks to Of 820 samples, 32 (4\%) unevaluable due to sample 2009 [66] 18 months mislabeling, damage or loss or missing/inconsistent data entries

Proportion of EID results returned:

Creek, $2008 \quad$ Botswana As above Of 930 tests performed at well child (clinic) visits, 753 results

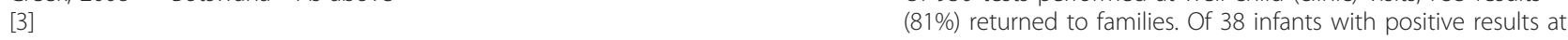
all sites, 34 results (90\%) returned to families

Chouraya, Swaziland Pilot EID program: HIV-exposed infants, aged $<12$ Of 124 infants with positive PCR results, 22 (18\%) started ART

IAS 2009 [59] months, with positive PCR results $\quad$ before pilot program (result receipt inferred), and 50 (40\%) were informed of results via pilot (total $=72(58 \%)$ of 124$)$. Additionally, 11 infants (9\%) died before pilot and 41 (33\%) were unable to be contacted; result receipt among these infants is unknown.

\begin{tabular}{|c|c|c|c|}
\hline $\begin{array}{l}\text { Kimario, } \\
\text { HAIM } 2009 \\
{[62]}\end{array}$ & Tanzania & As above & $\begin{array}{l}\text { Of 2,089 infants tested, } 1,331 \text { results (64\%) returned to facilities, } \\
\text { and } 774 \text { results (37\%) returned to families }\end{array}$ \\
\hline $\begin{array}{l}\text { Leroy, IAS } \\
2009[81]\end{array}$ & $\begin{array}{l}\text { Cote } \\
\text { d'lvoire }\end{array}$ & As above & Of 42 tested infants, 25 (60\%) of families returned for results \\
\hline $\begin{array}{l}\text { Rollins, } 2009 \\
{[68]}\end{array}$ & $\begin{array}{l}\text { South } \\
\text { Africa }\end{array}$ & As above & Of 584 infants tested, 332 mothers (57\%) returned for results \\
\hline $\begin{array}{l}\text { Sundaram, } \\
\text { IAS } 2009[69]\end{array}$ & Swaziland & $\begin{array}{c}\text { Retrospective review of HIV-infected infants diagnosed } \\
\text { via DBS PCR at } 15 \text { clinical sites }\end{array}$ & $\begin{array}{l}\text { Of } 176 \text { positive PCR results, } 137 \text { results (78\%) returned to } \\
\text { healthcare facility and } 77 \text { results (44\%) returned to families }\end{array}$ \\
\hline $\begin{array}{l}\text { Nuwagaba, } \\
2010[70]\end{array}$ & Tanzania & As above & $\begin{array}{l}\text { Of } 441 \text { tested infants, } 242(55 \%) \text { returned for results. Of } 75 \text { with } \\
\text { positive PCR results, } 51(68 \%) \text { returned for results; } 7 \text { (14\%) of } \\
\text { these children had died before result receipt. Of } 361 \text { with } \\
\text { negative PCR results, } 187(52 \%) \text { returned for results. Of five with } \\
\text { indeterminate PCR results, four (80\%) returned for results. }\end{array}$ \\
\hline
\end{tabular}


Table 1 Recent reports of early infant diagnostic testing programs in resource-limited settings: loss to follow-up at key steps in the 'cascade' of care (Continued)

Hassan, 2011 Kenya As above Of 156 infants tested, 110 (71\%) returned for results.

[76]

Time to return of EID results to healthcare facilities or families/caregivers:

Creek, 2008 Botswana As above Specimen collection to results return at healthcare facilities: 9

[3] $\quad$ days

Khamadi, Kenya As above Specimen collection to result return to families: range, 1-3

2008 [61] months.

Individual components:

Specimen collection to specimen receipt in laboratory: range, 6 hours to 3 weeks.

Specimen receipt in laboratory to result dispatch from laboratory: 2006-2007: median 13.5 days, range 6-20 days; 2008: median 4 days.

\begin{tabular}{llcl}
\hline $\begin{array}{l}\text { Kouakou, IAS } \\
2008[63]\end{array}$ & $\begin{array}{l}\text { Côte } \\
\text { d'Ivoire }\end{array}$ & As above & $\begin{array}{l}\text { Specimen receipt in laboratory to result return to facilities: 4-8 } \\
\text { weeks }\end{array}$ \\
\hline $\begin{array}{l}\text { Mahdi, IAS } \\
2008[65]\end{array}$ & $\begin{array}{l}\text { Swaziland } \\
\text { EID program and Public Health Unit: HIV-exposed } \\
\text { infants aged }<18 \text { months; } n=322\end{array}$ & 'Average turnaround time': 4-6 weeks \\
\hline Kimario, & Tanzania & As above & Turnaround time': 1-3 months
\end{tabular}

[62]

Lofgren, 2009 Tanzania As above

[28]

Specimen collection to result return to facilities: median 23 days, range 4-69 days (excluding single vacation period responsible for greatest delays: median 17 days, range 4-39 days).

Individual components:

Specimen collection to shipment from facilities: range 0-7 days.

Transit, facilities to laboratories: median 1.5 days, range 1-2 days. Laboratory processing: median 13 days, range 1-51 days (excluding single vacation period as above: median 7 days, range 1-21 days).

Completion of laboratory processing to shipment of results: range, $0-7$ days.

Transit, laboratories to facilities: median 1.5 days, range 1-2 days.

Rollins, 2009 South As above

[68] Africa scheduled visit 2 weeks after testing. Of 172 returning at another time, 138 (80\%) returned approximately 4 weeks after testing.

\begin{tabular}{llll}
\hline $\begin{array}{l}\text { Nuwagaba, } \\
2010[70]\end{array}$ & Tanzania & As above & $\begin{array}{l}\text { Positive PCR results: median } 5 \text { weeks, range }<1-14 \text { weeks. } \\
\text { Negative PCR results: median } 10 \text { weeks, range }<1-21 \text { weeks. }\end{array}$ \\
\hline $\begin{array}{l}\text { Hassan, } 2011 \\
{[76]}\end{array}$ & Kenya & As above & Waiting time to DBS results': median 1.7 months
\end{tabular}

Proportion of identified HIV-infected infants linking to HIV care:

\begin{tabular}{|c|c|c|c|}
\hline $\begin{array}{l}\text { Creek, } 2008 \\
{[3]}\end{array}$ & Botswana & As above & $\begin{array}{l}\text { Of } 34 \text { PCR-positive infants receiving results, } 22 \text { (65\%) were seen } \\
\text { in ART clinic }\end{array}$ \\
\hline $\begin{array}{l}\text { Kimario, } \\
\text { HAlM } 2009 \\
\text { [62] }\end{array}$ & Tanzania & As above & $\begin{array}{l}\text { Of } 190 \text { PCR-positive infants receiving results, } 175(92 \%) \text { were } \\
\text { referred to HIV care and treatment clinic, and } 149(78 \%) \\
\text { enrolled at clinic }\end{array}$ \\
\hline $\begin{array}{l}\text { Mahdi, IAS } \\
2008[65]\end{array}$ & Swaziland & As above & $\begin{array}{l}\text { Of } 19 \text { infants with positive PCR results, } 13 \text { (68\%) linked to HIV } \\
\text { care }\end{array}$ \\
\hline $\begin{array}{l}\text { Sundaram, } \\
\text { IAS } 2009[69]\end{array}$ & Swaziland & As above & $\begin{array}{l}\text { Of } 77 \text { PCR-positive infants receiving results, } 58 \text { (75\%) enrolled at } \\
\text { ART clinic }\end{array}$ \\
\hline $\begin{array}{l}\text { Nuwagaba, } \\
2010 \text { [70] }\end{array}$ & Tanzania & As above & $\begin{array}{l}\text { Of } 52 \text { PCR-positive infants receiving results, } 42(81 \%) \text { were } \\
\text { referred to HIV care (7 of } 52(14 \%) \text { had died when result was } \\
\text { received, and } 3 \text { of } 52(6 \%) \text { died between result receipt and } \\
\text { referral) }\end{array}$ \\
\hline $\begin{array}{l}\text { Braun, } 2011 \\
{[110]}\end{array}$ & Malawi & As above & $\begin{array}{l}\text { Of 1,084 infants with positive PCR results, } 320(30 \%) \text { were } \\
\text { traced to enrolment in an HIV care and treatment clinic }\end{array}$ \\
\hline \multicolumn{4}{|c|}{ Proportion of identified HIV-infected infants initiating cotrimoxazole: } \\
\hline $\begin{array}{l}\text { Augustinova, } \\
\text { IAS } 2009 \text { [89] }\end{array}$ & Cambodia & $\begin{array}{l}\text { Retrospective review of EID among HIV-exposed infants } \\
\text { aged }<18 \text { months at PMTCT and pediatric inpatient } \\
\text { and outpatient sites }\end{array}$ & $\begin{array}{l}\text { Of } 37 \text { infants with positive PCR results, } 13(35 \%) \text { initiated Ol } \\
\text { prophylaxis; an additional } 14(38 \%) \text { initiated ART (if Ol } \\
\text { prophylaxis inferred, total }=27 \text { of } 37(73 \%) \text { ) }\end{array}$ \\
\hline
\end{tabular}


Table 1 Recent reports of early infant diagnostic testing programs in resource-limited settings: loss to follow-up at key steps in the 'cascade' of care (Continued)

Proportion of identified HIV-infected infants initiating ART
Creek, 2008 Botswana As above
[3]

[3]
Of 22 infants enrolled in HIV clinic, 17 (77\%) initiated ART. These

17 infants represent $45 \%$ of the 38 infants with positive PCR results, and $50 \%$ of the 34 infants who received positive PCR results.

Mahdi, IAS Swaziland As above

2008 [65]

Augustinova, Cambodia As above

IAS 2009 [89]

Chouraya, Swaziland As above

IAS 2009 [59]

Of 13 PCR-positive infants linking to care, 5 (38\%) initiated ART.

These 5 infants represent 26\% of the 19 infants with positive PCR results.

Of 37 infants with positive PCR results, 14 (38\%) initiated ART

Of 124 infants with positive PCR results, 22 (18\%) initiated ART before pilot. Through EID pilot program, 25 additional infants (20\%) received results and initiated ART; total $=47$ of 124 (38\%). Additionally, 11 infants (9\%) died before the pilot program and 41 (33\%) were unable to be contacted through pilot; although unlikely, ART receipt among these infants is unknown.

\begin{tabular}{|c|c|c|c|}
\hline $\begin{array}{l}\text { Kimario, } \\
\text { HAIM } 2009 \\
{[62]}\end{array}$ & Tanzania & As above & $\begin{array}{l}\text { Of } 149 \text { PCR-positive infants enrolled in care and treatment } \\
\text { clinic, } 68(46 \%) \text { initiated ART. These } 68 \text { infants represent } 36 \% \text { of } \\
\text { the } 190 \text { results returned to families, and } 22 \% \text { of the } 310 \text { results } \\
\text { returned to facilities. }\end{array}$ \\
\hline $\begin{array}{l}\text { Sundaram, } \\
\text { IAS } 2009 \text { [69] }\end{array}$ & Swaziland & As above & $\begin{array}{l}\text { Of } 58 \text { infants enrolled at ART clinic, } 34 \text { (59\%) initiated ART. } \\
\text { These } 34 \text { infants represent 19\% of the } 176 \text { infants with positive } \\
\text { PCR results. }\end{array}$ \\
\hline $\begin{array}{l}\text { Braun, } 2011 \\
{[110]}\end{array}$ & Malawi & As above & $\begin{array}{l}\text { Of } 202 \text { PCR-positive infants enrolled in a care and treatment } \\
\text { clinic, } 110(55 \%) \text { initiated ART at a median } 2.5 \text { months after } \\
\text { enrollment }\end{array}$ \\
\hline
\end{tabular}

ANC = antenatal clinic; ART = antiretroviral therapy; CTX = cotrimoxazole; DBS = dried blood spot; EID = early infant diagnosis; HAIM = President's Emergency Plan for AIDS Relief (PEPFAR)-sponsored HIV/AIDS Implementers Meeting; IAS = International AIDS Society Conference; OI = opportunistic infection.

\section{Specimen collection and processing}

There are also major challenges in EID specimen collection and processing (Table 1). Reported rates of unevaluable specimens vary widely, from $0.03 \%$ to $16 \%$ $[61,64]$. Reasons for unevaluable specimens include errors in specimen collection, labeling, packaging and data entry, as well as damage or loss of specimens and assay failures in the laboratory $[3,28,61,63,66]$.

\section{Return of results to clinics and patients/caregivers} After EID assays are performed in the laboratory, results must next be returned to healthcare providers and then to families/caregivers. Rates of result return (37\% to $90 \%$ ) and time to result return (9 days to 21 weeks) range widely $[3,62,70]$. The time required for processing in the laboratory can be variable (1-51 days in a report from Tanzania) [28]. However, equally important events leading to lack of result return (Table 1) and delays in result return (Table 1) occur during the transmission of results from laboratory to healthcare providers and from providers to patients and families.

Currently, many central laboratories send paper-based EID results via commercial couriers, which may result in slow delivery $[61,83]$. Telephone-based and facsimilebased result return are limited by resource and internet availability, as well as laws regarding electronic transmission of health information [83,84]. Furthermore, health centers may lack systematic processes for following up test results. Because EID programs lie at the interface of PMTCT and pediatric programs [70] (in some cases, with separate health ministries overseeing each), there may be no clearly identified single agency responsible for ensuring that caregivers receive infant test results. Anecdotes describe single healthcare workers assuming this role; when these workers are absent, results may go unretrieved and unreturned [85,86]. In addition, since laboratory reports may be lost or delayed, EID results may not be available when caregivers return to receive them. The variability in result availability at patient return visits may be a more important reason for lack of patient result receipt than is failure of patients to keep follow-up appointments [76,83].

There is a clear need for improved medical informatics for laboratories and health centers [84]. Simple, inexpensive, and portable point-of-care DNA PCR and p24 antigen assays are also in development, but may be years from widespread use in remote settings [23,27,87]. In the interim, novel testing algorithms seek to minimize the need for return visits to receive results. For example, results of an antibody-based rapid HIV test (RHT) can be returned at an initial testing visit $[66,68,70,79]$. From 9-12 months of age, a negative RHT 
result can be reassuring with regard to both maternal and infant status, while a reactive result may motivate caregivers to return for the results of a PCR assay, which can be then performed on the same DBS sample used for the rapid test [55].

\section{Linkage to HIV care and treatment}

Finally, delays and losses to follow-up between receipt of positive HIV test results and the initiation of HIV care and ART are additional missed opportunities to improve pediatric health. Pre-ART losses to program have been less well described in children than in adults [88]. Where available, program reports have demonstrated that up to $35 \%$ of infants diagnosed through EID programs may fail to link to HIV treatment clinics (Table 1) [3]. A large proportion of children enrolling in HIV care may also experience delays in ART initiation (in some cases leading to pre-ART mortality) [59], or lack of appropriate ART initiation $[3,62,65,69,89]$. These studies must be interpreted in view of changing ART initiation guidelines during the study periods; because ART was only recently recommended for all HIV-infected infants, programs operating before 2008 would not have sought to place $100 \%$ of HIV-infected infants on ART $[6,10,32]$.

\section{Overall participation}

An 'index of participation' can be calculated to reflect successful completion of the EID cascade (Table 2). The index of participation is derived by multiplying the proportions of infants with successful uptake at each step in the cascade, prior to and including any given step of interest. For example, using the highest reported values of uptake at each step from Table 1, an estimated $87.9 \%$ of HIV-exposed infants would be expected to undergoing EID testing and receive test results. Using the lowest published values, this proportion would be $1.9 \%$. When extended to include linkage to HIV care and initiation of ART, the estimated rates of successful completion of the entire cascade range from $0.5 \%$ to $52.8 \%$, highlighting that even under the best reported conditions, nearly half of HIV-infected infants may not link successfully to care and ART.

\section{Economic analyses of EID testing algorithms}

Cost is often described as the principal barrier to the expansion of early infant diagnosis and ART [11], and a growing body of literature examines the current costs of EID programs. Here, we review published economic analyses of EID programs, focusing on three primary approaches: (1) costs to healthcare providers and HIV care programs, (2) costs to patients, and (3) cost effectiveness. The first approach, program-perspective or provider-perspective cost estimates, are valuable in planning short-term budgets for EID programs. However, these estimates omit important direct or indirect costs incurred by the families and caregivers of patients, which are included in the second approach. The third approach is the formal evaluation of cost effectiveness, which estimates the health and economic benefits obtained in return for investment in EID programs.

\section{Provider-perspective or program-perspective costs}

When EID costs are reported, most authors describe the cost, per patient tested, to healthcare providers or health programs $[3,11,23,61]$. Although purchase prices of DNA PCR test kits may be variably negotiated between governments and producers, published per-patient test kit prices range from $\$ 8.00$ in Botswana [3] to $\$ 50.00$ in South Africa (years of currency not reported) [90]. In addition to test kits, a Kenyan pilot program highlights other important costs (2007 US\$): insurance, freight, and taxes ( $\$ 4$ per specimen); filter papers ( $\$ 2$ per specimen); other reagents ( $\$ 4$ per specimen); courier services $(\$ 0.50$ per specimen); and personnel time (\$1 per specimen); combined with test kits costing $\$ 10.67$ per patient, these costs led to a total per-test cost of $\$ 22.17$ [61]. In Uganda, EID costs including personnel, supplies, and equipment totaled $\$ 23.90$ to $\$ 24.01$ (2007 US\$), with test kits comprising $55 \%$ of total costs [66]; in Botswana, incorporation of the costs of test kits, laboratory products, technician time, and machine maintenance led to an estimated total cost of $\$ 19.60$ per patient tested [3].

While these reports from Botswana, Kenya, and Uganda explicitly include many key costs $[3,61,66]$, five key components of EID programs are difficult to cost accurately and are omitted from many other EID program reports:

\section{Transport costs}

The costs of specimen transport from testing sites to processing laboratories, as well as the transport of results (electronically or on paper) back to providers, are infrequently described $[28,61]$.

\section{Laboratory costs}

Current assays for EID require substantial laboratory infrastructure, including not only PCR machines, laboratory space, and stable electricity, but also detailed and accurate systems for recording and delivering results. Reported assay costs usually include costs of disposable elements and reagents $[61,66]$, but less often incorporate amortized costs of PCR machines or ongoing machine maintenance costs $[3,23]$.

\section{Training costs}

Training costs are rarely reported, including training of phlebotomists, laboratory technicians and counselors, 
Table 2 Index of participation through each step in the early infant diagnosis (EID) cascade

\begin{tabular}{|c|c|c|c|}
\hline Step in cascade & $\begin{array}{l}\text { Highest value } \\
\text { from Table } 1\end{array}$ & $\begin{array}{l}\text { Lowest value } \\
\text { from Table } 1\end{array}$ & $\begin{array}{l}\text { Cumulative index of participation through step in } \\
\text { cascade (range, lowest to highest values from Table 1) }\end{array}$ \\
\hline $\begin{array}{l}\text { Proportion of exposed infants undergoing EID } \\
\text { testing }\end{array}$ & $98 \%[62]$ & $6 \%[81]$ & \\
\hline Specimen collection and processing & $\begin{array}{l}99.7 \% \\
\text { evaluable [61] }\end{array}$ & $\begin{array}{l}\text { 84\% evaluable } \\
\text { [64] }\end{array}$ & $5.9 \%$ to $97.7 \%$ \\
\hline Proportion of EID results returned & $90 \%[3]$ & $37 \%[62]$ & $1.9 \%$ to $87.9 \%$ \\
\hline $\begin{array}{l}\text { Proportion of infected infants linking to care (of } \\
\text { infected infants receiving results) }\end{array}$ & $78 \%[62]$ & $65 \%[3]$ & $1.2 \%$ to $68.6 \%$ \\
\hline $\begin{array}{l}\text { Proportion of infected infants initiating ART (of } \\
\text { infected infants receiving results and linking to care) }\end{array}$ & $77 \%[3]$ & $38 \%[65]$ & $0.5 \%$ to $52.8 \%$ \\
\hline
\end{tabular}

For each step in the EID cascade, the highest and lowest reported values from Table 1 are highlighted. The index of participation is calculated as the product of successful uptake through each step in the cascade. For example, the highest value of uptake through 'specimen collection and processing' is calculated as the product of the highest value for the prior step ('proportion of exposed infants undergoing EID testing', 98\%) and the highest value for the current step (99.7\%); $0.98 \times 0.997=0.9771$. Results highlight that even with the highest reported uptake values, the total proportion of infected infants successfully accessing all steps in the care cascade is low, at $52.81 \%$. As noted in the text, prior to 2008 , fewer than $100 \%$ of HIV-infected infants would have been recommended to initiate ART, and the estimate of $1.4 \%$ to $68.6 \%$ of infected infants linking to care may be a better reflection of cascade completion. These calculations are conducted for purposes of discussion only, and require the assumption that the prevalence of HIV-infected infants among those not accessing each step in the cascade is equal to the prevalence among infants accessing care.

ART $=$ antiretroviral therapy

for whom previous training may not have addressed ways to discuss results that reveal not only infant, but also maternal, HIV status [63,64,68].

\section{Quality control/quality assurance costs}

Available cost estimates exclude the cost of ongoing quality control and quality assurance programs. Such programs are likely to be both time and labor intensive when conducted thoroughly, for example via shipment and processing of standardized 'control' specimens [91], but are clearly needed to prevent rejection of up to $16 \%$ of specimens due to poor specimen quality (Table 1) [64].

\section{Healthcare delivery systems}

The economic impacts of variation in healthcare delivery systems are also rarely described, including anticipated reductions in per-test costs as greater numbers of infants are tested, reflecting economies of scale, and variations in cost between primary, district, and tertiary health centers. In addition, EID programs may be integrated into other maternal, neonatal, and child health programs. For example, return visits to receive EID test results are often scheduled alongside routine immunization visits [4]. An important consideration in EID cost analyses is the degree to which many of the costs described above are already included in existing maternal-child health program budgets.

\section{Patient or societal perspective costs}

The second approach to estimating EID costs incorporates not only costs to healthcare providers and programs, but also costs to patients, family members, and society. This 'societal perspective' includes both direct costs (money spent by health programs or patients) and indirect costs, such as wages lost when patients miss work to attend clinic appointments or when illness limits economic productivity. While societal-perspective cost estimates are more difficult to calculate and may be less directly useful to program directors planning shortterm budgets than program-perspective or provider-perspective estimates, they permit a more comprehensive evaluation of the economic impact of EID programs.

Sherman and colleagues in Johannesburg reported a cost analysis of an 'early diagnosis protocol', consisting of DBS PCR at 6 weeks of age, with a planned return visit to receive results at 3 months of age [4]. The early diagnosis protocol was compared to the standard diagnosis protocol at that time: HIV ELISA testing at 12 and 15-18 months. The early diagnosis protocol was estimated to identify $39 \%$ of all HIV-infected infants in the PMTCT program, compared to $15 \%$ identified by the standard protocol. In a provider-perspective cost analysis, the standard protocol cost $\$ 62.38$ per patient (2003 US\$) and the early diagnosis protocol cost $\$ 63.81$ per patient. In a societal-perspective analysis, direct patient expenditures (travel fare, refreshments) and indirect costs, such as forfeited wages, were included. In this analysis, due to a large number of clinic visits averted, the early diagnosis protocol was cost saving compared to the standard protocol ( $\$ 80.69$ vs. $\$ 107.51$ per patient). Extrapolating to all HIV-exposed infants in South Africa, the authors note that implementing the early diagnosis protocol would cost the health system over $\$ 400,000$ per year, but would lead to societal savings of $\$ 7.5$ million for those infants [4].

\section{Cost-effectiveness analysis}

Because the costs associated with EID in Africa are high relative to antibody-based strategies for HIV diagnosis 
(\$1 to $\$ 2$ per test [11]), program planners and policy makers must evaluate whether the benefits of EID programs are 'worth' their greater costs. Cost-effectiveness analysis is a formal methodology used to address this question, incorporating not only costs, but also clinical outcomes, of alternative health interventions. By convention, both current and future costs and savings are included. Similarly, both short-term and long-term clinical benefits are quantified, most often in either years of life saved (YLS) or quality-adjusted years of life saved (QALY, which value each year lived in imperfect health less than each year in perfect health) [92].

Using the cost and effectiveness outcomes for two alternative healthcare strategies, one can calculate an incremental cost-effectiveness ratio (ICER). The difference in costs between the competing strategies is the numerator, and the difference in effectiveness, or the incremental health benefit, comprises the denominator. ICERs are conventionally reported in \$/YLS or \$/QALY. Because these units are not specific to any single health condition, they can help inform decisions among a variety of health interventions for a given population. In addition, ICERs in \$/QALY can be compared to international standards of cost effectiveness, such as the WHOsupported Commission on Macroeconomics and Health recommendation that an intervention with an ICER less than the per capita GDP of a country be considered 'very cost effective' in that setting [93]. It is important to note that cost-effectiveness results are not intended to be the sole factor in health-related decision-making; issues of fairness, feasibility, and affordability may be of equal or greater importance.

The calculation of health benefits in YLS requires detailed information regarding both short-term and long-term survival associated with key possible health outcomes from the program under evaluation. For example, in an EID program, one would need estimates of the life expectancy of: (1) an HIV-infected child diagnosed and linked to HIV care through an EID program, (2) an HIV-infected child diagnosed and linked to care through a comparator program (for example, antibody testing at 15-18 months of age), (3) an HIV-exposed uninfected child, and (4) an HIV-unexposed child. Such life expectancy estimates, which may require long-term clinical studies or detailed computer simulation models to determine, are rarely available for resource-limited settings $[94,95]$. As a result, many cost-effectiveness analyses related to pediatric HIV prevention [96-99] or diagnosis $[66,100,101]$ have used a cost-effectiveness outcome of 'cost/case of pediatric HIV prevented' or 'cost/case of pediatric HIV diagnosed'. Although there are no international cost-effectiveness standards denominated in these units, if several cost-effectiveness analyses use the same outcome measure, the 'cost/case diagnosed' of a newly examined testing strategy can be compared to the 'cost/case diagnosed' of strategies previously described or currently in use.

Only one published study has examined the cost effectiveness of EID programs in resource-limited settings: a population of known HIV-exposed children in Uganda [66]. Using both a computer model and program data, the authors examined DBS-based strategies of DNA PCR for all infants ('PCR') and RHT followed by DNA PCR if RHT results were reactive ('RHT $\rightarrow$ PCR'). In all scenarios, RHT $\rightarrow$ PCR was less expensive; it was also less effective in most. Among known HIV-exposed infants in a 'poor compliance' scenario (with a $43 \%$ index of participation that is similar to many programs, Table $1[4,59,68,71])$, the ICER of the PCR algorithm compared to RHT $\rightarrow$ PCR was $\$ 539$ per 'infant correctly diagnosed and informed of result'. If RHT $\rightarrow$ PCR were the current practice, adopting the PCR algorithm would be economically efficient if policymakers were willing to pay $\$ 539$ to correctly diagnose one infant and inform him/her of test results. Because ICERs in such units are not directly comparable to other published cost-effectiveness outcomes, it remains challenging to answer the question, is the PCR algorithm cost effective in Uganda compared to the RHT $\rightarrow$ PCR algorithm? However, this detailed analysis demonstrates that the RHT $\rightarrow$ PCR algorithm may lead to nearly equivalent clinical outcomes and lower costs, and may become economically preferred in specific settings, for example where retention in care is high, breastfeeding is common, or HIV prevalence is low.

\section{Impact of the EID cascade on costs and cost effectiveness}

Current EID cost and cost-effectiveness analyses, combined with recent programmatic reports (Table 1), highlight the key factors that may effect both feasibility and cost effectiveness of EID programs in resource-limited settings. These factors reflect key steps along the 'cascade' of events required for effective EID and delineate high-priority areas of future research that will be needed to comprehensively assess the cost effectiveness of EID programs.

Proportion of HIV-exposed infants undergoing EID testing The numbers of infants who present for initial testing will dramatically impact the total costs and total benefits of an EID program. However, an increase in the number of infants tested may not impact the cost effectiveness of an EID program compared to deferred clinical or antibody-based diagnosis, since greater costs and greater benefits will accrue in both programs, and the incremental differences may be small. An important exception may occur if the prevalence of HIV exposure or 
HIV infection differs among the additional infants presenting for EID, as compared to deferred diagnosis. To best assess the cost effectiveness of sick-infant or 'universal testing' strategies, a formal evaluation of the demographics and HIV prevalence even of those not undergoing HIV testing (perhaps via anonymous seroprevalence studies) would be useful.

\section{Improvements in result receipt and linkage to HIV care}

The proportion of children and families who receive their EID test results and link to pediatric HIV care and ART will likely have a greater impact on the cost effectiveness than will the proportion of truly HIVexposed infants who seek EID testing. This occurs because children who undergo an EID test and are then lost to follow-up incur the cost of testing without receiving any benefit from early HIV care. As described previously, several innovative approaches to improve result return have been investigated, including screening via rapid HIV tests, followed by confirmatory PCR assays.

\section{HIV prevalence and populations targeted by EID programs}

The cost effectiveness of any screening program depends on the prevalence of disease in the screened population [102]. Menzies and colleagues found that the RHT $\rightarrow$ PCR algorithm, while cost saving, was slightly less effective than a strategy of PCR testing, in a population comprised entirely of HIV-exposed infants [66]. However, known HIV-exposed infants may not be the population in which an RHT $\rightarrow$ PCR algorithm would be most effective or cost effective. Among very young HIVexposed infants, negative RHTs are by definition false negatives with regard to maternal status and are therefore more likely to be false negatives with regard to infant infection status. False negativity may result from inherent test insensitivity, processing errors, or the 'window period' between postnatal infection and infant antibody production $[6,10]$. Among known HIV-exposed infants, then, routine PCR testing is more effective, and may also be cost effective. Rollins and colleagues investigated the $\mathrm{RHT} \rightarrow \mathrm{PCR}$ algorithm in a population in which it may be more cost effective: 'universal testing' at vaccination clinics $[68,82]$.

As proof of concept $[66,82]$ and feasibility and acceptability studies [68], both Menzies et al. and Rollins et al. processed DBS specimens for RHT [66] or ELISA $[68,82]$ and PCR off site, and were therefore unable to return antibody results to caregivers at the same visit on which samples were obtained. Additional evaluations of the RHT/PCR algorithm are needed in populations of infants without known HIV exposure, with specific focus on the proportions of infants/caregivers receiving immediate RHT results, receiving delayed PCR results, and linking to HIV care.

\section{Long-term clinical and economic impacts of early infant diagnosis and care}

To comprehensively assess the cost effectiveness of EID compared to traditional deferred diagnostic strategies, it will be critical to understand the clinical events and costs associated with early and late diagnosis and therapy. These factors may have greater impact on EID cost effectiveness than the comprehensive costs of laboratory assays including transport, equipment, training, and quality assurance. The immediate costs for PCR-based EID are higher than for deferred antibody-based testing [11]. Medication costs associated with early diagnosis will increase further if infants link to HIV services and early ART. Considering short-term benefits, such as the number of infants diagnosed, does not capture the larger clinical benefits of early diagnosis and therapy [33,103]. In addition, EID and early ART initiation will likely avert a large number of opportunistic infections and deaths [33,103], for which care is expensive; in the short term, this may offset a proportion of the upfront costs of EID programs [104]. For example, substantial cost savings were observed over a 10-month period in South Africa when ART was initiated immediately after EID, compared to ART deferred until the development of signs or symptoms of AIDS [34]. Data to inform clinical outcomes for HIV-exposed and HIV-infected children in various resource-limited settings are needed. As such data become available, health policy models $[66,95]$ can integrate data from multiple sources, highlight future research priorities by identifying the most influential data parameters, and assist in informing HIV testing and treatment guidelines.

\section{Conclusions}

Access to early infant diagnosis of HIV infection is improving in resource-limited settings, but key barriers exist to testing, result receipt, and linkage to care. Infants of mothers who are unaware of their own HIV infections or who did not access PMTCT services may be the most difficult population to capture, but may also be the population with the greatest need for EID. The benefits of successful EID are substantial, not only for HIV-infected infants, in whom morbidity and mortality can be reduced with early ART initiation, but also for HIV-negative infants, their caregivers, and PMTCT and pediatric providers. Costs are a frequently cited barrier to EID expansion. However, more detailed cost-effectiveness analyses will be important to assess the degree to which the benefits of EID programs render them 'worth' their costs, and long-term data and model-based projections can further inform future clinical and 
economic benefits. Innovative approaches to improve rates of testing, result receipt, and linkage to care will have lasting impacts on the health of HIV-exposed infants and the value of EID programs in resource-limited settings.

\section{Acknowledgements}

The authors gratefully acknowledge Asinath Rusibamayila and Sarah Bancroft Lorenzana for assistance in manuscript and figure preparation. Funding for this work was provided by the National Institute of Allergy and Infectious Disease (K01 Al078754 (ALC), R01 Al058736 (KAF, RPW, JP), the National Institute of Child Health and Human Development (T32HD 055148-02 (LR)), the Elizabeth Glaser Pediatric AIDS Foundation (ALC, JP, KF, RPW), and the French National Institute of Health and Medical Research (VL). The funders had no role in study design; in the collection, analysis, and interpretation of data; in the writing of the manuscript; or in the decision to submit the manuscript for publication.

\section{Author details}

'Division of Infectious Disease, Massachusetts General Hospital, Boston, MA, USA. 'Division of General Medicine, Massachusetts General Hospital, Boston, MA, USA. 'Division of Infectious Diseases, Children's Hospital Boston, Boston, MA, USA. ${ }^{4}$ Center for AIDS Research, Harvard Medical School, Boston, MA, USA. ${ }^{5}$ Division of Infectious Disease, Brigham and Women's Hospital, Boston, MA, USA. Inserm, Unité 897, Institut de Santé Publique, Epidémiologie et Développement (ISPED), Université Bordeaux Segalen, Bordeaux, France.

\section{Authors' contributions}

ALC conceived the study, conducted literature review, data extraction, and interpretation of results, and drafted the manuscript. JP conducted literature review and data extraction. JP, LRA, KAF, RPW, and VL participated in the design of the study and interpretation of study results. All authors critically reviewed the manuscript and contributed to manuscript drafting, and all authors read and approved the final submitted manuscript.

\section{Competing interests}

The authors declare that they have no competing interests.

Received: 15 March 2011 Accepted: 20 May 2011

Published: 20 May 2011

\section{References}

1. UNAIDS/UNICEF/WHO: Children and AIDS: Fourth stocktaking report, actions and progress.[http://www.unicef.org/publications/index_46585. html].

2. World Health Organization: Towards universal access: Scaling up priority HIV/AIDS interventions in the health sector. Progress Report.[http://www. who.int/hiv/pub/2010progressreport/report/en/index.html].

3. Creek T, Tanuri A, Smith M, Seipone K, Smit M, Legwaila K, Motswere C, Maruping M, Nkoane T, Ntumy R, Bile E, Mine M, Lu L, Tebele G, Mazhani L, Davis MK, Roels TH, Kilmarx PH, Shaffer N: Early diagnosis of human immunodeficiency virus in infants using polymerase chain reaction on dried blood spots in Botswana's national program for prevention of mother-to-child transmission. Pediatr Infect Dis J 2008, 27:22-26.

4. Sherman GG, Matsebula TC, Jones SA: Is early HIV testing of infants in poorly resourced prevention of mother to child transmission programmes unaffordable? Trop Med Int Health 2005, 10:1108-1113.

5. Barker PM, Mphatswe W, Rollins N: Antiretroviral drugs in the cupboard are not enough: the impact of health Systems' performance on motherto-child transmission of HIV. J Acquir Immune Defic Syndr 2010, 56:e45-48.

6. World Health Organization: Antiretroviral therapy for HIV infection in infants and children: Recommendations for a public health approach (2010 version).[http://www.who.int/hiv/pub/paediatric/infants2010/en/ index.html].

7. Chantry CJ, Cooper ER, Pelton SI, Zorilla C, Hillyer GV, Diaz C: Seroreversion in human immunodeficiency virus-exposed but uninfected infants. Pediatr Infect Dis J 1995, 14:382-387.
8. Sohn A, Le Q, Truong X, Le T, Truong H, Wara D, Cachafeiro A, Rutherford G: Abstract 670: The utrasensitive p24 antigen assay is comparable to DNA PCR for early infant diagnosis, Ho Chi Minh City, Vietnam. Conference on Retroviruses and Opportunistic Infections. Los Angeles. 2007 [http://www.retroconference.org/2007/Abstracts/28425.htm].

9. Dabis F, Msellati P, Dunn D, Lepage P, Newell M, Peckham C, Van de Perre $P$, the Working Group on Mother-to-Child Transmission of HIV: Estimating the rate of mother-to-child transmission of HIV. Report of a workshop on methodological issues; Ghent (Belgium), 17-20 February 1992. AIDS 1993, 7:1139-1148.

10. World Health Organization: Antiretroviral therapy of HIV infection in infants and children: towards universal access. Recommendations for a public health approach.[http://www.who.int/hiv/pub/guidelines/art/en/ index.html].

11. Creek TL, Sherman GG, Nkengasong J, Lu L, Finkbeiner T, Fowler MG, Rivadeneira $\mathrm{E}$, Shaffer $\mathrm{N}$ : Infant human immunodeficiency virus diagnosis in resource-limited settings: issues, technologies, and country experiences. Am J Obstet Gynecol 2007, 197:S64-71.

12. Read JS: Diagnosis of HIV-1 infection in children younger than 18 months in the United States. Pediatrics 2007, 120:e1547-1562.

13. Lambert JS, Harris DR, Stiehm ER, Moye J Jr, Fowler MG, Meyer WA, Bethel J, Mofenson LM: Performance characteristics of HIV-1 culture and HIV-1 DNA and RNA amplification assays for early diagnosis of perinatal HIV-1 infection. J Acquir Immune Defic Syndr 2003, 34:512-519.

14. Young NL, Shaffer N, Chaowanachan T, Chotpitayasunondh T, Vanparapar N, Mock PA, Waranawat N, Chokephaibulkit K, Chuachoowong R, Wasinrapee P, Mastro TD, Simonds RJ, Bangkok Collaborative Perinatal HIV Transmission Study Group: Early diagnosis of HIV-1-infected infants in Thailand using RNA and DNA PCR assays sensitive to non-B subtypes. J Acquir Immune Defic Syndr 2000, 24:401-407.

15. Nielsen $\mathrm{K}$, Bryson YJ: Diagnosis of HIV infection in children. Pediatr Clin North Am 2000, 47:39-63.

16. Owens DK, Holodniy M, MCDonald TW, Scott J, Sonnad S: A meta-analytic evaluation of the polymerase chain reaction for the diagnosis of HIV infection in infants. JAMA 1996, 275:1342-1348.

17. Dunn DT, Brandt CD, Krivine A, Cassol SA, Roques P, Borkowsky W, De Rossi A, Denamur E, Ehrnst A, Loveday C: The sensitivity of HIV-1 DNA polymerase chain reaction in the neonatal period and the relative contributions of intra-uterine and intra-partum transmission. AIDS 1995, 9:F7-11.

18. Garcia-Prats A, Draper H, Sanders J, Agrawal A, Mohapi E, Schutze G: Post18 month confirmatory HIV testing in HIV DNA PCR positive children: retrospective descriptive analysis from an operational setting in Lesotho. International AIDS Society. Vienna, Austria; 2010 [http://pag.aids2010.org/ Abstracts.aspx?SID=644\&AID=17231].

19. Eberle J, Notheis G, Blattmann C, Jung J, Buchholz B, Korn K, Kulozik AE, Schnitzler P: Seroreversion in vertically HIV-1-infected children treated early and efficiently: rule or exception? AIDS 24:2760-2761.

20. Patton JC, Coovadia AH, Meyers TM, Sherman GG: Evaluation of the ultrasensitive human immunodeficiency virus type 1 (HIV-1) p24 antigen assay performed on dried blood spots for diagnosis of HIV-1 infection in infants. Clin Vaccine Immunol 2008, 15:388-391.

21. Fiscus SA, Wiener J, Abrams EJ, Bulterys M, Cachafeiro A, Respess RA: Ultrasensitive p24 antigen assay for diagnosis of perinatal human immunodeficiency virus type 1 infection. J Clin Microbiol 2007, 45:2274-2277.

22. Knuchel MC, Jullu B, Shah C, Tomasik Z, Stoeckle MP, Speck RF, Nadal D, Mshinda H, Böni J, Tanner M, Schüpbach J: Adaptation of the ultrasensitive HIV-1 p24 antigen assay to dried blood spot testing. J Acquir Immune Defic Syndr 2007, 44:247-253.

23. Jangam S, McFall S, Yamada D, Sur K, Agarwal A, Wagner R, Kelso D: Abstract 891: A point-of-care DNA PCR test for infants. Conference on Retroviruses and Opportunistic Infections. San Francisco; 2010 [http:// retroconference.org/2010/Abstracts/39114.htm].

24. Parpia Z, Elghanian R, Nabatiyan A, Hardie D, Kelso D: Abstract 968: Evaluation of a rapid lateral flow p24 assay for the diagnosis of HIV in infants. Conference on Retroviruses and Opportunistic Infections. Montreal, Canada; 2009 [http://www.retroconference.org/2009/Abstracts/36378.htm].

25. Cachafeiro A, Sherman GG, Sohn AH, Beck-Sague C, Fiscus SA: Diagnosis of human immunodeficiency virus type 1 infection in infants by use of 
dried blood spots and an ultrasensitive p24 antigen assay. J Clin Microbiol 2009, 47:459-462

26. Wittawatmongkol O, Vanprapar N, Chearskul P, Phongsamart W, Prasitsuebsai W, Sutthent R, Chokephaibulkit K: Boosted p24 antigen assay for early diagnosis of perinatal HIV infection. J Med Assoc Thai 2010, 93:187-190.

27. Parpia ZA, Elghanian R, Nabatiyan A, Hardie DR, Kelso DM: p24 antigen rapid test for diagnosis of acute pediatric HIV infection. J Acquir Immune Defic Syndr 2010, 55:413-419.

28. Lofgren SM, Morrissey AB, Chevallier CC, Malabeja Al, Edmonds S, Amos B, Sifuna DJ, von Seidlein L, Schimana W, Stevens WS, Bartlett JA, Crump JA: Evaluation of a dried blood spot HIV-1 RNA program for early infant diagnosis and viral load monitoring at rural and remote healthcare facilities. AIDS 2009, 23:2459-2466.

29. Sherman GG, Jones SA: Oral fluid human immunodeficiency virus tests: improved access to diagnosis for infants in poorly resourced prevention of mother to child transmission programs. Pediatr Infect Dis J 2005, 24:253-256.

30. Mehta N, Trzmielina S, Nonyane BA, Eliot MN, Lin R, Foulkes AS, McNeal K, Ammann A, Eulalievyolo V, Sullivan JL, Luzuriaga K, Somasundaran M: Lowcost HIV-1 diagnosis and quantification in dried blood spots by real time PCR. PLoS One 2009, 4:e5819.

31. Sherman G, Technau K, Kalk E, Hampton G, Khan S, Bhowan K, Selepe N, Barrie L, Carmona S, Goga A, Olorunju S, Manda S, Coovadia A: Earlier diagnosis of HIV infection in infants in low resource settings. 5th IAS Conference on HIV Pathogenesis and Treatment Cape Town, South Africa; 2009 [http://www.lasociety.org/Default.aspx? pageld=11\&abstractld=200721991], Abstract no. WEPEB267.

32. World Health Organization: Report of the WHO Technical Reference Group Pediatric HIV ART/Care Guideline Group Meeting.[http://www.who int/hiv/pub/paediatric/WHO_Paediatric_ART_guideline_rev_mreport_2008. $\mathrm{pdf}]$.

33. Violari A, Cotton MF, Gibb DM, Babiker AG, Steyn J, Madhi SA, JeanPhilippe P, McIntyre JA: CHER Study Team: Early antiretroviral therapy and mortality among HIV-infected infants. N Engl J Med 2008, 359:2233-2244

34. Meyer-Rath G, Violari A, Cotton M, Ndibongo B, Brenna A, Long L, Panchia R, Coovadia A, Gibb DM, Rosen S: THLBB103: The cost of early vs. deferred paediatric antiretroviral treatment in South Africa - a comparative economic analysis of the first year of the CHER trial. International AIDS Society. Vienna, Austria; 2010 [http://pag.aids2010.org/ Abstracts.aspx?SID=644\&AID=17823].

35. Chadwick EG, Rodman JH, Britto P, Powell C, Palumbo P, Luzuriaga K, Hughes M, Abrams EJ, Flynn PM, Borkowsky W, Yogev R: PACTG Protocol 345 Team: Ritonavir-based highly active antiretroviral therapy in human immunodeficiency virus type 1-infected infants younger than 24 months of age. Pediatr Infect Dis J 2005, 24:793-800.

36. Chiappini E, Galli L, Tovo PA, Gabiano C, Gattinara GC, Guarino A, Badolato R, Giaquinto C, Lisi C, de Martino M: Italian Register for HIV Infection in Children: Virologic, immunologic, and clinical benefits from early combined antiretroviral therapy in infants with perinatal HIV-1 infection. AIDS 2006, 20:207-215.

37. Faye A, Le Chenadec J, Dollfus C, Thuret I, Douard D, Firtion G, Lachassinne E, Levine M, Nicolas J, Monpoux F, Tricoire J, Rouzioux C, Tardieu M, Mayaux MJ, Blanche S, French Perinatal Study Group: Early versus deferred antiretroviral multidrug therapy in infants infected with HIV type 1. Clin Infect Dis 2004, 39:1692-1698.

38. Varga CA, Sherman GG, Maphosa J, Jones SA: Psychosocial consequences of early diagnosis of HIV status in vertically exposed infants in Johannesburg, South Africa. Health Care Women Int 2005, 26:387-397.

39. World Health Organization: Principles and recomendations for infant feeding in the context of HIV and a summary of evidence.[http://www. who.int/child_adolescent_health/documents/9789241599535/en/index.html].

40. Thior I, Lockman S, Smeaton LM, Shapiro RL, Wester C, Heymann SJ, Gilbert PB, Stevens L, Peter T, Kim S, van Widenfelt E, Moffat C, Ndase P, Arimi P, Kebaabetswe P, Mazonde P, Makhema J, Mclntosh K, Novitsky V Lee TH, Marlink R, Lagakos S, Essex M, Mashi Study Team: Breastfeeding plus infant zidovudine prophylaxis for 6 months vs formula feeding plus infant zidovudine for 1 month to reduce mother-to-child HIV transmission in Botswana: a randomized trial: the Mashi Study. JAMA 2006, 296:794-805
41. Persaud D, Bedri A, Ziemniak C, Moorthy A, Gudetta B, Abashawl A, Mengistu Y, Omer SB, Isehak A, Kumbi S, Adamu R, Lulseged S, Ashworth R, Hassen E, Ruff A, The Ethiopian Swen Study Team: Slower clearance of nevirapine resistant virus in infants failing extended nevirapine prophylaxis for prevention of mother-to child HIV-transmission. AIDS Res Hum Retroviruses 2011

42. Moorthy A, Gupta A, Bhosale R, Tripathy S, Sastry J, Kulkarni S, Thakar M, Bharadwaj R, Kagal A, Bhore AV, Patil S, Kulkarni V, Venkataramani V, Balasubramaniam U, Suryavanshi N, Ziemniak C, Gupte N, Bollinger R, Persaud D: Nevirapine resistance and breast-milk HIV transmission: effects of single and extended-dose nevirapine prophylaxis in subtype $C$ HIV-infected infants. PLoS One 2009, 4:e4096.

43. World Health Organization: HIV and infant feeding: Revised Principles and Recommendations Rapid Advice.[http://whalibdoc.who.int/publications/ 2009/9789241598873_eng.pdf].

44. Kuhn L, Aldrovandi GM, Sinkala M, Kankasa C, Semrau K, Mwiya M, Kasonde P, Scott N, Vwalika C, Walter J, Bulterys M, Tsai WY, Thea DM: Zambia Exclusive Breastfeeding Study: Effects of early, abrupt weaning on HIV-free survival of children in Zambia. N Engl J Med 2008, 359:130-141.

45. Becquet R ED, Menan H, Amani-Bosse C, Bequet L, Viho I, Dabis F, TimiteKonan M, Leroy V: Early mixed feeding and breastfeeding beyond 6 months increase the risk of postnatal HIV transmission: ANRS 1201/1202 Ditrame Plus, Abidjan, Cote d'Ivoire. Prevent Med 2008, 47:27-33.

46. Horwood C, Vermaak K, Rollins N, Haskins L, Nkosi P, Qazi S: Paediatric HIV management at primary care level: an evaluation of the integrated management of childhood illness (IMCI) guidelines for HIV. BMC Pediatr 2009, 9:59.

47. Iliff P, Ntozini R, Nathoo K, Piwoz E, Moulton L, ZVITAMBO Study Group, Humphrey J: Making a working clinical diagnosis of HIV infection in infants in Zimbabwe. Trop Med Int Health 2008, 13:1459-1469.

48. Kumar D, Aggarwal AK, Kumar R: The effect of interrupted 5-day training on integrated management of neonatal and childhood illness on the knowledge and skills of primary health care workers. Health Policy Plan 2009, 24:94-100.

49. Jaspan H, Myer L, Violari A, Madhi S, Steyn J, van Niekerk R, Stevens W, Cotton M: Abstract \#76: Clinical and immunological characteristics of very young infants with HIV infection: Children with HIV Early Antiretroviral Study. Conference on Retroviruses and Opportunistic Infections Boston, MA; 2008 [http://www.retroconference.org/2008/Abstracts/31111. $\mathrm{htm}$.

50. Arrivé E, Kyabayinze DJ, Marquis B, Tumwesigye N, Kieffer MP, Azondekon A, Wemin L, Fassinou P, Newell ML, Leroy V, Abrams EJ, Cotton M, Boulle A, Mbori-Ngacha D, Dabis F, KIDS-ART-LINC Collaboration: Cohort profile: The paediatric Antiretroviral Treatment Programmes in Lower-Income Countries (KIDS-ART-LINC) Collaboration. Int J Epidemiol 2007, 37:474-480.

51. Ciaranello A, Chang Y, Margulis A, Bernstein A, Bassett IV, Losina E, Walensky RP: Effectiveness of pediatric ART in resource-limited settings: a systematic review and meta-analysis. Clin Infect Dis 2009, 49:1915-1927.

52. UNAIDS/UNICEF/WHO: Children and AIDS: Third stocktaking report, actions and progress.[http://www.unicef.org/publications/index_46585. html]

53. Akinwande O, Omoigberale A, Onakewhor J, Esene H, Chime C, Sadoh W, Enzama R, Farley J, Abimiku A: Abstract no. CDC011: Early infant diagnosis (EID) as a tool to assess PMTCT effectiveness and challenges 5th IAS Conference on HIV Pathogenesis and Treatment. Cape Town, South Africa; 2009 [http://www.iasociety.org/Default.aspx? pageld=11\&abstractld=200721554].

54. Somlare H, Sangare L, Yamegogo S, Ouedraogo C, Dembel Y, Soro M, Some $\mathrm{P}$, Yonaba C: Early diagnosis of HIV-1 infection in infants using RNA Quantitative PCR in Burkina Faso. Retrovirology 2009, 6:P10.

55. Bolu O, Abutu A, Omeogu C, Nwude C, Akpan R, et al: Abstract 747: Benefits of routine HIV screening of sick children in Nigeria. The 2008 HIV/AIDS Implementers' Meeting Kampala, Uganda; 2008, 47[http://www. hivimplementers.com/2008/pdf/OGAC_08_BookHR.pdf].

56. Gautney B, Segaren N, Khamadi S: Abstract no. CDA087: Private and public partnership: a model for a national HIV early infant diagnosis program in Haiti. 5th IAS Conference on HIV Pathogenesis and Treatment Cape Town, South Africa; 2009 [http://www.ias2009.org/pag/Abstracts.aspx? $\mathrm{AID}=1654]$. 
57. Mushavi A, Dillavou C, Sawadogo S, Witbooi D, Gawanab M, Soroses F, Rusberg F: Abstract 1000, page 92: Namibia's early infant diagnosis program from January 2006 to September 2008. The 2009 HIV/AIDS Implementers' Meeting Windhoek, Namibia; 2009 [http://www. hivimplementers.com/pdfs/FINALAbstractBook.pdf].

58. Ncube B, Freeman R, Murtagh M, Peter T: Abstract no. LBPE1152: The global scale-up of early infant diagnosis by DNA PCR: lessons from a review of select country programs. AIDS 2008 - XVII International AIDS Conference Mexico City, Mexico; 2008, International AIDS Society, Geneva, Switzerland

59. Chouraya C, Mahdi MA, Kieffer MP, Lukhele B: Abstract no. CDB078: Implementing early antiretroviral treatment for infants in Swaziland $5^{\text {th }}$ IAS Conference on HIV Pathogenesis and Treatment. Cape Town, South Africa; 2009 [http://www.ias2009.org/pag/Abstracts.aspx?AID=2545].

60. Gidada BG, Ashenafi A, Negash Y, Ruff A, Wegderes H, Tesema M, Doherty M: Abstract 1286, page 137: EID program scale up and partnership with regional laboratories for sustainability. The 2009 HIV/ AIDS Implementers' Meeting Windhoek, Namibia; 2009 [http://www. hivimplementers.com/pdfs/FINALAbstractBook.pdf].

61. Khamadi S, Okoth V, Lihana R, Nabwera J, Hungu J, Okoth F, Lubano K, Mwau M: Rapid identification of infants for antiretroviral therapy in a resource poor setting: the Kenya experience. J Trop Pediatr 2008, 54:370-374.

62. Kimario CJ, Schimana W, Charles D, Teri IE, Giphart A, Marlinc R, McCullough R, Lee S, VantPadBosch J: Abstract 887, page 79: Scale up of early infant diagnosis (EID) in Tanzania: experience from the Elizabeth Glaser Pediatric AIDS Foundation. The 2009 HIV/AIDS Implementers' Meeting Windhoek, Namibia; 2009 [http://www.hivimplementers.com/pdfs/ FINALAbstractBook.pdf].

63. Kouakou J, Nobah MT, Tanoh A, Fassinou P, Essombo J: Abstract no. MOPE0217, page 103: Preliminary results of the demonstration phase of routine early HIV testing of HIV-exposed infants identified through PMTCT programs in Côte d'IIvoire. AIDS 2008 - XVII International AIDS Conference Mexico City, Mexico; 2008 [http://www.aids2008-abstracts.org/ aids2008_book_vol1_web.pdf].

64. Kouakou JS, Nobah M, Tanoh AR, Fassinou P, Borget M, Noba V Aghokeng A, Rivadeneira E, Ou C, Dao H: Abstract 1645, page 135: Routine early HIV testing of HIV-exposed infants in PMTCT programs in Côte d'Ivoire. The 2008 HIV/AIDS Implementers' Meeting Kampala, Uganda; 2008 [http://www.hivimplementers.com/2008/pdf/OGAC 08 BookHR.pdf].

65. Mahdi MA, Chouraya C, Waligo A, Shabalat F, Kieffer MP: Abstract no. MOPE0223, page 104: Early infant diagnosis (EID): Swaziland experience. AIDS 2008 - XVIII International AIDS Conference Mexico City, Mexico; 2008 [http://www.aids2008-abstracts.org/aids2008_book_vol1_web.pdf].

66. Menzies NA, Homsy J, Chang Pitter JY, Pitter C, Mermin J, Downing R, Finkbeiner T, Obonyo J, Kekitiinwa A, Tappero J, Blandford JM: Costeffectiveness of routine rapid human immunodeficiency virus antibody testing before DNA-PCR testing for early diagnosis of infants in resource-limited settings. Pediatr Infect Dis J 2009, 28:819-825.

67. Nyathi M, Ndebele W, Ndebele B, Mbizvo E, Mudzori J, et al: Abstract no. CDB0442: Recruitment of infants for early infant diagnosis of HIV using DNA PCR testing in Zimbabwe: lessons learned from a national pilot project. AIDS 2008 - XVIII International AIDS Conference Mexico City, Mexico; 2008, International AIDS Society, Geneva, Switzerland.

68. Rollins N, Mzolo S, Moodley T, Esterhuizen T, van Rooyen H: Universal HIV testing of infants at immunization clinics: an acceptable and feasible approach for early infant diagnosis in high HIV prevalence settings. AIDS 2009, 23:1851-1857.

69. Sundaram M, Lukhele B: Abstract no. MOPDD103: Identification patient loss points from testing to treatment initiation among infants tested in Swaziland. 5th IAS Conference on HIV Pathogenesis and Treatment Cape Town, South Africa; 2009 [http://www.ias2009.org/pag/Abstracts.aspx? $\mathrm{AID}=1981]$.

70. Nuwagaba-Biribonwoha H, Werq-Semo B, Abdallah A, Cunningham A, Gamaliel JG, Mtunga S, Nankabirwa V, Malisa I, Gonzalez LF, Massambu C, Nash D, Justman J, Abrams EJ: Introducing a multi-site program for early diagnosis of HIV infection among HIV-exposed infants in Tanzania. BMC Pediatr 2010, 10:44

71. Dow A, Dube Q, Chirambo CM, Moore M, Heyderman R, Van Rie A: Abstract no. CDB098: Community based early infant testing and treatment: experience from Blantyre, Malawi $5^{\text {th }}$ IAS Conference on HIV
Pathogenesis and Treatment. Cape Town, South Africa; 2009 [http://www. iasociety.org/Default.aspx? pageld=11\&abstractld=200721828].

72. Guay L: SUSSO3: Scaling up early infant diagnosis as the bridge between prevention, care, and treatment. International AIDS Society. Vienna; 2010 [http://pag.aids2010.org/session.aspx?s=150].

73. Kellerman S, Essajee S: HIV testing for children in resource-limited settings: what are we waiting for? PloS Med 2010, 7:285-285.

74. Mugwagwa R: The Child Health Card as a linkage tool: experiences from Zimbabwe. International AIDS Society. Cape Town, South Africa; 2009 [http://www.docstoc.com/docs/55372155/lssues-around-pre-test-revised-C]

75. Evjen-Olsen B, Olsen OE, Kvale G: Achieving progress in maternal and neonatal health through integrated and comprehensive healthcare services - experiences from a programme in northern Tanzania. Int J Equity Health 2009, 8:27.

76. Hassan AS, Sakwa EM, Nabwera HM, Taegtmeyer MM, Kimutai RM Sanders EJ, Awuondo KK, Mutinda MN, Molyneux CS, Berkley JA: Dynamics and constraints of early infant diagnosis of HIV infection in rural Kenya. AIDS Behav

77. Lu L, Legwaila K, Motswere C, Smit M, Jimbo W, Creek T: Abstract 91: HIV incidence in pregnancy and the first post-partum year and implications for PMTCT programs, Francistown, Botswana, 2008. Conference on Retroviruses and Opportunistic Infections. Montreal 2009 [http:// retroconference.org/2009/Abstracts/34193.htm]

78. Dunn DT, Newell ML, Ades AE, Peckham CS: Risk of human immunodeficiency virus type 1 transmission through breastfeeding. Lancet 1992, 340:585-588,

79. Wanyenze RK, Nawavvu C, Ouma J, Namale A, Colebunders R, Kamya MR: Provider-initiated HIV testing for paediatric inpatients and their caretakers is feasible and acceptable. Trop Med Int Health 2010, 15:113-119.

80. Weigel R, Kamthunzi P, Mwansambo C, Phiri S, Kazembe PN: Effect of provider-initiated testing and counselling and integration of ART services on access to HIV diagnosis and treatment for children in Lilongwe, Malawi: a pre-post comparison. BMC Pediatr 2009, 9:80.

81. Leroy V BH, Oga M, Yapo V, Bosse-Amani C, Dago-Akribi H, Menan H, Ekouevi D, Timite-Konan M: Family acceptability of pediatric HIV counseling and testing offered routinely during postnatal care for children under 6 months of age, in Abidjan, Côte d'Ivoire. International AIDS Society. Cape Town, South Africa; 2009 [http://www.las2009.org/pag/ Abstracts.aspx?AID=2290]

82. Rollins N, Little K, Mzolo S, Horwood C, Newell ML: Surveillance of motherto-child transmission prevention programmes at immunization clinics: the case for universal screening. AIDS 2007, 21:1341-1347.

83. Forum for Collaborative HIV Research: HIV Diagnostic and Monitoring Technologies in Resource Limited Settings. Washington, D.C.; 2009 [http:// www.hivforum.org/index.php? option=com_content\&task=view\&id=278\&ltemid $=65]$

84. Douglas GP, Gadabu OJ, Joukes S, Mumba S, McKay MV, Ben-Smith A, Jahn A, Schouten EJ, Landis Lewis Z, van Oosterhout JJ, Allain TJ, Zachariah R, Berger SD, Harries AD, Chimbwandira F: Using touchscreen electronic medical record systems to support and monitor national scale-up of antiretroviral therapy in Malawi. PLoS Med 2010, 7: e1000319.

85. Creek T: Early infant diagnosis in Botswana: Program and data use HIV Diagnostic and Monitoring Technologies in Resource Limited Settings. Washington, D.C.; 2009 [http://www.hivforum.org/index.php? option=com_content\&task=view\&id=278\&ltemid=65].

86. Horwood C, Haskins L, Vermaak K, Phakathi S, Subbaye R, Doherty T: Prevention of mother to child transmission of HIV (PMTCT) programme in KwaZulu-Natal, South Africa: an evaluation of PMTCT implementation and integration into routine maternal, child and women's health services. Trop Med Int Health

87. Parpia Z, Elghanian R, Nabatiyan A, Hardie D, Kelso D: Abstract 892: Evaluation of a carbon nanoparticle-based rapid p24 assay for the diagnosis of HIV in infants: results from Cape Town. Conference on Retroviruses and Opportunistic Infections. San Francisco 2010 [http:// retroconference.org/2010/Abstracts/39264.htm].

88. Losina E, Bassett IV, Giddy J, Chetty S, Regan S, Walensky RP, Ross D, Scott CA, Uhler LM, Katz JN, Holst H, Freedberg KA: The "ART" of linkage: pre-treatment loss to care after HIV diagnosis at two PEPFAR sites in Durban, South Africa. PLoS One 2010, 5:e9538. 
89. Augustinova D, Stranska A, Koum K, Ean S, Vong S, Kong C, Ngin S, Nerrienet $E$, Bandak M: Effectiveness of a district-wide programme for the prevention of mother-to-child transmission of HIV in Cambodia. Experience from six maternity units in Phnom Penh and Kandal. International AIDS Society. Cape Town, South Africa 2009 [http://www. ias2009.org/pag/Abstracts.aspx?AID=2321]

90. Creek T, Ntumy R, Mazhani L, Moore J, Smith M, Han G, Shaffer N, Kilmarx PH: Factors associated with low early uptake of a national program to prevent mother to child transmission of HIV (PMTCT): Results of a survey of mothers and providers, Botswana, 2003. AIDS Behav 2009, 13:356-364.

91. Banda W, Mwenda R, Porter C, Yang C, Hersey S, Moyo H, Nyangulu L, Eliya M, Kamoto K, Demby A: Abstract 966, page 87: Establishing laboratory quality assurance for early infant diagnosis. The 2009 HIV/AIDS Implementers' Meeting Windhoek, Namibia; 2009 [http://www. hivimplementers.com/pdfs/FINALAbstractBook.pdf].

92. Gold MR, Siegel JE, Russell LB, Weinstein MC: Cost-Effectiveness in Health and Medicine New York: Oxford University Press; 1996.

93. World Health Organization: WHO-CHOICE: Cost-effectiveness thresholds. [http://www.who.int/choice/costs/CER_thresholds/en/index.html].

94. Maclean CC, Stringer JS: Potential cost-effectiveness of maternal and infant antiretroviral interventions to prevent mother-to-child transmission during breast-feeding. J Acquir Immune Defic Syndr 2005, 38:570-577.

95. Aledort JE, Ronald A, Le Blancq SM, Ridzon R, Landay A, Rafael ME, Shea MV, Safrit J, Peeling RW, Hellmann N, Mwaba P, Holmes K, Wilfert C: Reducing the burden of HIV/AIDS in infants: the contribution of improved diagnostics. Nature 2006, 444(Suppl 1):19-28.

96. Grobman WA, Garcia PM: The cost-effectiveness of voluntary intrapartum rapid human immunodeficiency virus testing for women without adequate prenatal care. Am J Obstet Gynecol 1999, 181:1062-1071.

97. Rely K, Bertozzi SM, Avila-Figueroa C, Guijarro MT: Cost-effectiveness of strategies to reduce mother-to-child HIV transmission in Mexico, a lowprevalence setting. Health Policy Plan 2003, 18:290-298.

98. Chen KT, Sell RL, Tuomala RE: Cost-effectiveness of elective cesarean delivery in human immunodeficiency virus-infected women(1). Obstet Gynecol 2001, 97:161-168.

99. Stringer JS, Rouse DJ: Rapid testing and zidovudine treatment to prevent vertical transmission of human immunodeficiency virus in unregistered parturients: a cost-effectiveness analysis. Obstet Gynecol 1999, 94:34-40.

100. Mrus JM, Yi MS, Eckman MH, Tsevat J: The impact of expected HIV transmission rates on the effectiveness and cost of ruling out HIV infection in infants. Med Decis Making 2002, 22:S38-44.

101. Doyle NM, Levison JE, Gardner MO: Rapid HIV versus enzyme-linked immunosorbent assay screening in a low-risk Mexican American population presenting in labor: a cost-effectiveness analysis. Am J Obstet Gynecol 2005, 193:1280-1285.

102. Agency for Healthcare Research and Quality: Screening for human immunodeficiency birus: focused update of a 2005 systematic evidence review for the U.S. Preventive Services Task Force.[http://www. uspreventiveservicestaskforce.org/uspstf07/hiv/hivrevup.pdf].

103. Prendergast A, Mphatswe W, Tudor-Williams G, Rakgotho M, Pillay V Thobakgale C, McCarthy N, Morris L, Walker BD, Goulder P: Early virological suppression with three-class antiretroviral therapy in HIV-infected African infants. AIDS 2008, 22:1333-1343.

104. Cleary SM, McIntyre D, Boulle AM: The cost-effectiveness of antiretroviral treatment in Khayelitsha, South Africa - a primary data analysis. Cost Eff Resour Alloc 2006, 4:20.

105. Sohn AH, Thanh TC, Thinh le Q, Khanh TH, Thu HK, Giang le T, Lien TX: Failure of human immunodeficiency virus enzyme immunoassay to rule out infection among polymerase chain reaction-negative Vietnamese infants at 12 months of age. Pediatr Infect Dis J 2009, 28:273-276.

106. Dabis F, Bequet L, Ekouevi DK, Viho I, Rouet F, Horo A, Sakarovitch C, Becquet R, Fassinou P, Dequae-Merchadou L, Welffens-Ekra C, Rouzioux C, Leroy V, ANRS 1201/1202 DITRAME PLUS Study Group: Field efficacy of zidovudine, lamivudine and single-dose nevirapine to prevent peripartum HIV transmission. AIDS 2005, 19:309-318.

107. Mphatswe W, Blanckenberg N, Tudor-Williams G, Prendergast A Thobakgale C, Mkhwanazi N, McCarthy N, Walker BD, Kiepiela P, Goulder P: High frequency of rapid immunological progression in African infants infected in the era of perinatal HIV prophylaxis. AIDS 2007, 21:1253-1261.
108. Mofenson LM, Korelitz J, Meyer WA, Bethel J, Rich K, Pahwa S, Moye J Jr, Nugent $R$, Read J: The relationship between serum human immunodeficiency virus type 1 (HIV-1) RNA level, CD4 lymphocyte percent, and long-term mortality risk in HIV-1-infected children. National Institute of Child Health and Human Development Intravenous Immunoglobulin Clinical Trial Study Group. J Infect Dis 1997, 175:1029-1038.

109. Shearer WT, Quinn TC, LaRussa P, Lew JF, Mofenson L, Almy S, Rich K, Handelsman E, Diaz C, Pagano M, Smeriglio V, Kalish LA: Viral load and disease progression in infants infected with human immunodeficiency virus type 1. Women and Infants Transmission Study Group. N Engl J Med 1997, 336:1337-1342.

110. Braun M, Kabue MM, McCollum ED, Ahmed S, Kim M, Aertker L, Chirwa M, Eliya M, Mofolo I, Hoffman I, Kazembe PN, van der Horst C, Kline MW, Hosseinipour MC: Inadequate coordination of maternal and infant HIV services detrimentally affects early infant diagnosis outcomes in Lilongwe, Malawi. J Acquir Immune Defic Syndr 2011

\section{Pre-publication history}

The pre-publication history for this paper can be accessed here: http://www.biomedcentral.com/1741-7015/9/59/prepub

doi:10.1186/1741-7015-9-59

Cite this article as: Ciaranello et al:: Early infant HIV-1 diagnosis programs in resource-limited settings: opportunities for improved outcomes and more cost-effective interventions. BMC Medicine 2011 9:59.

\section{Submit your next manuscript to BioMed Central and take full advantage of:}

- Convenient online submission

- Thorough peer review

- No space constraints or color figure charges

- Immediate publication on acceptance

- Inclusion in PubMed, CAS, Scopus and Google Scholar

- Research which is freely available for redistribution 